\title{
Detection of enterotoxin A and cytotoxin B, and isolation of Clostridium difficile in piglets in Minas Gerais, Brazil
}

\author{
Detecção da enterotoxina A e citotoxina B e isolamento de Clostridium difficile em leitões em Minas \\ Gerais, Brasil
}

\author{
Rodrigo Otávio Silveira Silva ${ }^{\mathrm{I}}$ Felipe Masiero Salvarani ${ }^{\mathrm{I}}$ Eduardo Coulaud da Costa Cruz Júnior ${ }^{\mathrm{I}}$ \\ Prhiscylla Sadanã Pires ${ }^{I}$ Renata Lara Resende Santos ${ }^{I}$ Ronnie Antunes de Assis ${ }^{I I}$ \\ Roberto Maurício de Carvalho Guedes ${ }^{\mathrm{I}}$ Francisco Carlos Faria Lobato $^{\mathrm{I}}$
}

\begin{abstract}
Clostridium difficile has emerged as a major cause of neonatal colitis in piglets, displacing classic bacterial pathogens. However, there is no information regarding the distribution of this microorganism in pig farms in Brazil. In the present study, the presence of toxins $A / B$ and of $C$. difficile strains in stool samples from 60 diarrheic or non-diarrheic newborn piglets (one to seven days old), from 15 different farms, was studied. The presence of toxins $A / B$ was detected by ELISA and PCR was used to identify toxin $A$, toxin $B$ and binary toxin gene in each isolated strain. $C$. difficile $A / B$ toxins were detected in ten samples (16.7\%). Of these, seven were from diarrheic and three were from non-diarrheic piglets. $\boldsymbol{C}$. difficile was recovered from 12 out of 60 (20\%) fecal samples. Of those, three strains were non-toxigenic $\left(A^{-} B^{-}\right)$and nine were toxigenic. Of the nine toxigenic strains, four were $A^{+} B^{+}$strains and five were $A^{-} B^{+}$strains. The presence of binary toxin observed in the present study was much higher (50\%) than in previously reported studies. All three non-toxigenic strains were isolated from otherwise healthy piglets. The results suggest the occurrence of neonatal diarrhea by $\boldsymbol{C}$. difficile in farms in Brazil.
\end{abstract}

Key words: Neonatal diarrhea, Clostridium difficile, enteritis, colitis.

\section{RESUMO}

Clostridium difficile tem sido relatado como o principal causador de colite neonatal em suínos. Apesar da crescente importância deste agente, não há dados sobre infecções causadas por $\boldsymbol{C}$. difficile em suínos no Brasil. $O$ objetivo do presente estudo foi detectar as toxinas $A / B$ e isolar C. difficile a partir de 60 amostras de fezes de leitões diarreicos

\begin{abstract}
ou apararentemente saudáveis, com no máximo sete dias de $v i d a$, e oriundos de 15 granjas diferentes. As toxinas $A / B$ foram detectadas por ELISA e uma PCR multiplex foi utilizada para detecção dos genes responsáveis pela codificação das toxinas $A, B$ e toxina binária. As toxinas $A / B$ de $C$. difficile foram detectadas em dez amostras de fezes (16.7\%). Dessas, sete eram de animais diarreicos e três de leitões aparentemente saudáveis. Foi possivel isolar C. difficile em 12 das 60 (20\%) amostras trabalhadas. Dessas, três estirpes eram não-toxigênicas $\left(A^{-} B^{-}\right)$ e nove eram toxigênicas, sendo quatro caracterizadas como $A^{+} B^{+}$e cinco como $A^{-} B^{+}$. O gene responsável pela codificação da toxina binária foi encontrado em $50 \%$ das estirpes isoladas, proporção superior ao relatado em estudos anteriores. Todas as estirpes não toxigênicas foram isoladas de animais não diarreicos. Os resultados encontrados sugerem a ocorrência de diarreia por $\boldsymbol{C}$. difficile em granjas no Brasil.
\end{abstract}

Palavras-chave: diarreia neonatal, Clostridium difficile, colite, enterite.

\section{INTRODUCTION}

Clostridium difficile is a spore-forming, anaerobic, Gram-positive bacillus that has been recognized as an important bacterial pathogen in both humans and animals. According to BARTLETT (1992), C. difficile may be responsible for $95 \%$ of all pseudomembranous colitis cases and most cases of antibiotic-associated diarrhea in humans. Most isolates of $\boldsymbol{C}$. difficile produce two types of toxins that damage the colonic epithelium: toxin $\mathrm{A}$, an enterotoxin, and

'Laboratório de Bacteriose e Pesquisa, Escola de Veterinária, Universidade, Federal de Minas Gerais (UFMG), 30123-970, Belo Horizonte, MG, Brasil. E-mail: flobato@vet.ufmg.br.*Autor para correspondência.

ISetor de Clostridioses, Ministério da Agricultura, Pecuária e Abastecimento, LANAGRO-MG, Pedro Leopoldo, MG, Brasil. 
toxin B, a cytotoxin (VOTH \& BALLARD, 2005). In addition to these two major toxins, it has been suggested that a binary toxin, also called $\boldsymbol{C}$. difficile transferase (CDT), may be an additional important virulence factor (STUBBS et al., 2000). It consists of two independent unlinked proteins chains that are encoded by two separate genes, designated $c d t A$ and $c d t B$, and according to SCHWAN et al. (2009), the binary toxin may increase the adherence and colonization of the bacterium.

In veterinary medicine, $\boldsymbol{C}$. difficile has been implicated as a cause of enteric disease in a variety animal species including adult horses, foals, dogs and rabbits (BAVERUD, 2002). In swine, the importance of C. difficile as an agent involved in porcine neonatal diarrhea has increased, displacing classic bacterial pathogens (SONGER \& UZAL, 2005). It has been suggested that $\boldsymbol{C}$. difficile may be currently the most important uncontrolled cause of neonatal diarrhea in pigs (SCHWAN et al, 2009).

Laboratory diagnosis of $\boldsymbol{C}$. difficile infection is based on detection of toxin A and/or toxin B by cell culture or by enzyme immunoassays (ELISA) (DELMEÉ, 2001). Moreover, isolation and screening for toxin genes leads to a better understanding of transmission patterns and risk factors and is useful for detecting variant strains that produce only one of the major toxins. The evaluation of the distribution of these strains and the potential association with the occurrence of diarrhea are important factors for elucidating the epidemiology of this disease (ARROYO et al., 2007; BARBUT et al., 2005).

Despite of the importance of $\boldsymbol{C}$. difficile as a swine pathogen, there are no current clear data concerning the distribution of this microorganism in pig farms in Brazil. Therefore, the aim of this study was to detect $\boldsymbol{C}$. difficile $\mathrm{A} / \mathrm{B}$ toxins and to isolate strains of $\boldsymbol{C}$. difficile in stool samples from diarrheic and nondiarrheic piglets.

\section{MATERIAL AND METHODS}

Stool samples were collected from 60 piglets, aged 1 to 7 days, from 15 different pig farms located in a densely swine-populated area in Minas Gerais, Brazil. In each farm, samples from two diarrheic and two nondiarrheic piglets were collected $(n=60)$. All samples were stored at $20^{\circ} \mathrm{C}$ and processed within 72 hours after collection.

C. difficile $\mathrm{A} / \mathrm{B}$ toxins were detected using an ELISA kit (Ridascreen Clostridium difficile toxins A/B, R-Biopharm, Germany). The reaction was carried out in accordance to the manufacturer's instructions.
To select $\boldsymbol{C}$. difficile spores, equal volumes of stool samples and ethanol 96\% (v/v) were mixed, and after incubation for 20 minutes at room temperature (AVBERSEK et al., 2009), aliquots of $100 \mu 1$ were inoculated on plates containing cycloserine-cefoxitin fructose agar (CFFA, Hi-media, Mumbai) supplemented with $7 \%$ horse blood. These plates were incubated anaerobically at $37^{\circ} \mathrm{C}$ for 48 hours. All colonies with suggestive morphology, Gram stain appearance and typical horse-manure odor (FEDORKO \& WILLIAMS,

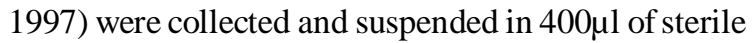
Milli-Q water. The DNA extraction was performed according to BAUMS et al. (2004), and samples were stored at $4^{\circ} \mathrm{C}$ until used in the PCR assay.

Genes encoding toxins A $(t c d A), \mathrm{B}(t c d B)$ and binary toxin $(c d t B)$ were detected by multiplexPCR. Briefly, $5 \mu$ of DNA extract was added to a PCR mixture containing $1.5 \mathrm{mM} \mathrm{MgCl}_{2}, 50 \mathrm{mM} \mathrm{KCl}, 10 \mathrm{mM}$

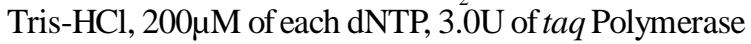
(Phoneutria ${ }^{\circledR}$, Belo Horizonte, Brazil) and the 8 primers shown at the table 1 , at the concentrations given. The tpi-specific primers were deduced from alignments of internal fragments of the tpi gene, a housekeeping gene from $C$. difficile. The $t c d B$-specific primers were designed from a conserved region of the $t c d B$ gene. The $t c d A$-specific primers were designed to flank the smallest of the three deletions in the $3^{\prime}$ region of the tcdA gene characterized in $\mathrm{A}^{-} \mathrm{B}^{+}$variant strains and generated a 369-bp fragment for $\mathrm{A}^{+} \mathrm{B}^{+}$strains and a 110-bp fragment for $\mathrm{A}^{-} \mathrm{B}^{+}$strains (LEMEE et al., 2004). The $c d t B$-specific primers were previously described by PERSSON et al (2008) and were designed from a conserved region of the $c d t B$ gene, which is responsible for the codification of the binding component of the binary toxin from $\boldsymbol{C}$. difficile. The final reaction volume was $25 \mu$ l. Amplifications were carried out in a thermocycler (Thermal Cycler Px2 Thermo Electron Corporation, Milford, USA) and consisted of a denaturation step of $5 \mathrm{~min}$ at $95^{\circ} \mathrm{C}$, followed by 35 cycles of $30 \mathrm{~s}$ at $95^{\circ} \mathrm{C}$ for denaturation, 30 s at $52^{\circ} \mathrm{C}$ for annealing and $30 \mathrm{~s}$ at $72^{\circ} \mathrm{C}$ for extension. A final extension cycle of $10 \mathrm{~min}$ at $72^{\circ} \mathrm{C}$ was also added. The positive and negative controls were a reference strain of $\boldsymbol{C}$. difficile (ATCC 9689) and sterile Milli-Q water, respectively. Amplification products were visualized under UV light in a $2 \%$ agarose gel stained with ethidium bromide (Sigma-Aldrich, Saint Louis, USA). C. difficile isolates were considered toxigenic based on the presence of genes encoding toxin A, B or both (RUPNIK et al., 2005).

Chi-square tests were used to evaluate possible association between dependent variables and clinical groups. $\mathrm{P}$ values of $<0.05$ were considered significant. 
Table 1 - Primers used in multiplex-PCR for detection of genes encoding toxins A $(t c d A), \mathrm{B}(t c d B)$, binary toxin $(c d t B)$ and $t p i$ gene from $\boldsymbol{C}$. difficile.

\begin{tabular}{|c|c|c|c|c|c|}
\hline $\begin{array}{l}\text { Gene } \\
\text { target }\end{array}$ & Primer name & Sequence $\left(5^{\prime}-3{ }^{\prime}\right)$ & $\begin{array}{l}\text { Primer concentration } \\
\qquad(\mu \mathrm{M})\end{array}$ & $\begin{array}{l}\text { Amplicon size } \\
\text { (bp) }\end{array}$ & Reference \\
\hline \multirow{2}{*}{$\operatorname{tcd} A$} & tcdA_F & AGATTCCTATATTTACATGACAATAT & 1.0 & \multirow{2}{*}{365 or 110} & \multirow{6}{*}{$\begin{array}{l}\text { LEMEE et al } \\
(2004)\end{array}$} \\
\hline & tcdA_R & GTATCAGGCATAAAGTAATATACTTT & 1.0 & & \\
\hline \multirow{2}{*}{$t c d B$} & tcdB_F & GGAAAAGAGAATGGTTTTATTAA & 0.5 & \multirow{2}{*}{160} & \\
\hline & tcdB_R & ATCTTTAGTTATAACTTTGACATCTTT & 0.5 & & \\
\hline \multirow{2}{*}{$t p i$} & tpi_F & AA AGAAGCTACTAAGGGTACAAA & 0.5 & \multirow{2}{*}{210} & \\
\hline & tpi_R & CATAATATTGGGTCTATTCCTAC & 0.5 & & \\
\hline \multirow[b]{2}{*}{$c d t B$} & cdtB_F & TTGACCCAAAGTTGATGTCTGATTG & 0.5 & \multirow{2}{*}{262} & \multirow{2}{*}{$\begin{array}{l}\text { PERSSON et al } \\
(2008)\end{array}$} \\
\hline & cdtB_R & CGGATCTCTTGCTTCAGTCTTTATAG & 0.5 & & \\
\hline
\end{tabular}

\section{RESULTS}

For detection of $\boldsymbol{C}$. difficile A/B toxins, 10 samples $(16.7 \%)$ were positive (Table 2 ). From these, seven were from diarrheic piglets, and three were from non-diarrheic piglets. There was no significant association between the detection of toxin $A / B$ and the presence of diarrhea.

C. difficile was recovered from 12 of 60 (20\%) stool samples. Of those, three strains were nontoxigenic $\left(\mathrm{A}^{-} \mathrm{B}^{-}\right)$and nine were toxigenic (Table 3 ). Among these nine strains, four were $\mathrm{A}^{+} \mathrm{B}^{+}$and five were variant strains $\left(\mathrm{A}^{-} \mathrm{B}^{+}\right)$. The binary toxin genes were detected in six $(50 \%)$ strains, all of which were toxigenic (Table 4). Considering only the farms, $\boldsymbol{C}$. difficile was recovered from eight (53.3\%) out of 15 visited farms.

\section{DISCUSSION}

In the present study, $16.7 \%$ of the animals were positive for $\boldsymbol{C}$. difficile A/B toxins. These results are lower than those described by YAEGER et al. (2007) in which $50 \%(62 / 159)$ of the piglets tested positive. The significantly large percentage of positives found by those authors is likely because of the larger number of animals suspected to have $\boldsymbol{C}$. difficile infection (100/ 129). In another similar study, the presence of toxins $A$

Table 2 - Detection of toxins A and B from $\boldsymbol{C}$. difficile by ELISA in stool samples from piglets in Brazil.

\begin{tabular}{llc}
\hline \multirow{2}{*}{ Piglets } & \multicolumn{2}{c}{---o------ELISA (\%)----------- } \\
& Positives & Negatives \\
\hline Diarrheic & $7(11.7)$ & $23(38.3)$ \\
Non-diarrheic & $3(5 \%)$ & $27(45 \%)$ \\
Total & $10(16.7)$ & $50(83.3)$ \\
\hline
\end{tabular}

and B was observed in $58 \%$ of the piglets, however all piglets examined were with enteritis (SONGER et al., 2007).

The presence of non-diarrheic animals, although positive in the detection of toxins A and B both corroborates with YAEGER et al. (2007), which noted that was common to see piglets infected with $\boldsymbol{C}$. difficile but without any clinical sign. However, those animals are positive for detection of toxins and have intestinal lesions when subjected to histopathological evaluation. It suggests that, in piglets, $\boldsymbol{C}$. difficile infection could be subclinical, making difficult the perception of the disease on a farm. It is also interesting to remember that there are studies that suggest that most of the ELISA kits have a good specificity but a variable sensitivity (between 30 and $80 \%$ ) when used with swine feces, which can lead to false-negative results (POST et al., 2002; SONGER et al., 2007).

No clear association between isolation of this bacteria and neonatal porcine diarrhea was detected, in agreement with previous studies in pigs (ALVAREZ-PEREZet al., 2009; AVBERSEK et al., 2009). The isolation rate obtained $(20 \%)$ was slightly lower than that reported by ALVAREZ-PEREZ et al. (2009) that recovered $\boldsymbol{C}$. difficile from $25.9 \%$ of piglets, which were also one to seven days of age, from farms in Spain. In the present research, three non-toxigenic and five variant strains were isolated from four different farms. In contrast, ALVAREZ-PEREZ et al. (2009) reported a much lower rate of non-toxigenic and variants strains than observed in this study. Among 140 recovered strains, ALVAREZ-PEREZ et al. (2009) identified only seven non-toxigenic (5\%) strains and one variant strain $(0.7 \%)$, all from the same farm.

Differences in isolation rates may result from differences in management practices, clustering of cases (ARROYO et al., 2007) and of differences in geographical distribution. A recent study also 
Table 3 - PCR detection of $t c d A$ and $t c d B$ from $C$. difficile isolated from diarrheic and non-diarrheic piglets 1 to 7 days old.

\begin{tabular}{llllc}
\hline \multirow{2}{*}{ Piglets } & \multicolumn{4}{c}{-----Clostridium difficile strains (\%)----- } \\
& $\mathrm{A}^{+} \mathrm{B}^{+}$ & \multicolumn{1}{c}{$\mathrm{AB}^{+}$} & $\mathrm{AB}^{-}$ & Total \\
\hline Diarrheic & $3(25)$ & $2(16.7)$ & $0(0)$ & $5(41.7)$ \\
Non-diarrheic & $1(8.3)$ & $3(25)$ & $3(25)$ & $7(58.3)$ \\
Total & $4(33.3)$ & $5(41.7)$ & $3(25)$ & $12(100)$ \\
\hline
\end{tabular}

suggested prevalent variation in certain genotypes of C. difficile in different geographic regions (AVBERSEK et al., 2009). In addition, the carrier state of $\boldsymbol{C}$. difficile seems to vary among asymptomatic individuals by species and within the same species, depending on age and other population characteristics (KEEL \& SONGER, 2006).

According to ARROYO et al. (2007), the high frequency of variant strains may complicate the diagnosis of diarrhea due to $\boldsymbol{C}$. difficile since there are several commercial ELISA kits designed to detect only toxin A, which might cause false-negative results. Additionally, variant strains have been involved in nosocomial outbreaks in humans (ALFA et al., 2000; KUIJPER et al., 2001).

In this study, all non-toxigenic strains were isolated from healthy animals, corroborating the findings of ALVAREZ-PEREZ et al. (2009). According to SONGER et al. (2007), inoculation of piglets at birth with a non-toxigenic $\boldsymbol{C}$. difficile strain significantly reduced the effects of $\boldsymbol{C}$. difficile infection on performance. In humans, according to KYNE et al. (2000), previous colonization by a non-toxigenic or a toxigenic strain reduces the risk of developing diarrhea associated with $\boldsymbol{C}$. difficile. As a result, a non-toxigenic strain for competitive exclusion is under development for use in at-risk humans (SONGER, 2010).

Little is known about the clinical relevance and pathogenic role of CDT in $\boldsymbol{C}$. difficile infections and most studies are related to human patients. The

Table 4 - Presence of binary toxin genes of $\boldsymbol{C}$. difficile strains isolated from diarrheic and non-diarrheic piglets.

\begin{tabular}{llll}
\hline \multirow{2}{*}{ C. difficile strains } & \multicolumn{2}{c}{ Binary toxin $(\%)$} & Total \\
& CDT & CDT $^{+}$ & \\
\hline $\mathrm{A}^{+} \mathrm{B}^{+}$ & $3(25)$ & $1(8.3)$ & $4(33.3)$ \\
$\mathrm{AB}^{-}$ & $0(0)$ & $5(41.7)$ & $5(41.7)$ \\
$\mathrm{AB}^{-}$ & $3(25)$ & $0(0)$ & $3(25)$ \\
Total & $6(50)$ & $6(50)$ & $12(100)$ \\
\hline
\end{tabular}

presence of binary toxin $\left(\mathrm{CDT}^{+}\right)$observed in the present study was much higher $(50 \%)$ than in previously reported studies. PERSSON et al. (2008), working with samples isolated from humans, reported that the prevalence of $\mathrm{CDT}^{+}$strains was $26 \%, 97.3 \%$ of which were $\mathrm{A}^{+} \mathrm{B}^{+}$. ARROYO et al. (2007) found only $4 \%$ of strains were $\mathrm{CDT}^{+}$in a study with diarrheic horses. AVBERSEK et al. (2009) also detected binary toxin genes in $\boldsymbol{C}$. difficile strains isolated from piglets, but the $\mathrm{CDT}^{+}$rate was not reported. Also, the absence of non-toxigenic strains positive for binary toxin corroborates previous studies (ARROYO et al., 2007; PERSSON et al., 2008; STUBBS et al., 2000). According to STUBBS et al. (2000), binary toxin genes are commonly observed in strains that possess some part of the pathogenicity locus containing the genes for toxins A and B. As CDT is a potent cytotoxin, GONÇALVES et al. (2004) suggested that it might prepare the way for toxins A and B. Alternatively, CDT can also act in synergy with other toxins, depolymerizing the cytoskeleton by a complementary mechanism. The high presence of $\mathrm{CDT}^{+}$strains observed in the present study underlines the importance of more research to elucidate the role of CDT in neonatal colitis in piglets.

Recently, C. difficile has been isolated from ready-to-eat retail meats and salads. Many of these strains were of ribotypes associated with $\boldsymbol{C}$. difficile infection in humans and food animals (RODRIGUEZPALACIOS et al., 2007; BAKRI et al., 2009; SONGER et al., 2009). It is also important to note that the two most common toxigenic ribotypes in pigs, which account for $90 \%$ and $80 \%$ of isolates, respectively, are also recognized as causes of $\boldsymbol{C}$. difficile disease in humans (ARROYO et al., 2007). All these reports raise the possibility of $\boldsymbol{C}$. difficile infection as a zoonotic disease, but more studies are needed for elucidation.

The results suggest the occurrence of neonatal diarrhea by $\boldsymbol{C}$. difficile in farms in Brazil. Further studies could be useful to evaluate the minimum inhibitory concentrations of the most common antibiotics used on swine farms against $\boldsymbol{C}$. difficile strains. This is the first study about toxin detection and isolation of $\boldsymbol{C}$. difficile from piglets in Brazil.

\section{ACKNOWLEDGMENTS}

This research was supported by funds from Coordenação de Aperfeiçoamento de Pessoal de Nível Superior (Capes), Fundação de Amparo à Pesquisa do Estado de Minas Gerais (Fapemig) and Conselho Nacional de Desenvolvimento Científico e Tecnológico (CNPq). 


\section{REFERENCES}

ALFA, M.J. et al. Characterization of a toxin A-negative, toxin B-positive strain of Clostridium difficile responsible for a nosocomial outbreak of Clostridium difficile-associated diarrhea. Jounal of Clinical Microbiology, v.38, n.7, p.2706-2714, 2000. Avaliable from: <http://www.ncbi.nlm.nih.gov/pubmed/ 10878068>. Accessed: May 20, 2011.

ALVAREZ-PEREZ, S. et al. Prevalence of Clostridium difficile in diarrhoeic and non-diarrhoeic piglets. Veterinary Microbiology, v.137, n.4, p.302-305, 2009. Avaliable from: <http://www.ncbi.nlm.nih.gov/pubmed/19200665>. Accessed: May 20, 2011. doi: 10.1016/j.vetmic.2009.01.015.

ARROYO, L.G. et al. Molecular analysis of Clostridium difficile isolates recovered from horses with diarrhea. Veterinary Microbiology, v.120, p.179-183, 2007. Avaliable from: <http:/ /www.ncbi.nlm.nih.gov/pubmed/17112686>. Accessed: May 20, 2011. doi: $10.1016 /$ j.vetmic. 2006.10.013.

AVBERSEK, J. et al. Diversity of Clostridium difficile in pigs and other animals in Slovenia. Anaerobe, v.15, n.6, p.252255, 2009. Avaliable from: <http://www.ncbi.nlm.nih.gov/ pubmed/19632350>. Accessed: May 20, 2011. doi: 10.1016/ j.anaerobe.2009.07.004.

BAKRI, M.M. et al. Clostridium difficile in ready-to-eat salads, Scotland. Emerging Infectious Diseases Journal, v.15, n.5, p.817-818, 2009. Avaliable from: <http://www.ncbi.nlm.nih.gov/ pubmed/19402979>. Accessed: May 20, 2011.

BARBUT, F. et al. Clinical features of Clostridium difficileassociated diarrhoea due to binary toxin (actin-specific ADP ribosyltransferase)-producing strains. Jounal of Clinical Microbiology, v.54, p.181-185, 2005. Avaliable from: <http:/ /www.ncbi.nlm.nih.gov/pubmed/15673514>. Accessed: May 20, 2011.

BARTletT, J.G. Antibiotic-associated diarrhea. Clinical Infectious Diseases, v.15, n.4, p.573-581, 1992. Avaliable from: <http://www.ncbi.nlm.nih.gov/pubmed/1420669>. Accessed: May 20, 2011.

BAVERUD, V. Clostridium difficile infections in animals with special reference to the horse. A review. Vet Q Journal, v.24, n.4, p.203-219, 2002. Avaliable from: <http:// www.ncbi.nlm.nih.gov/pubmed/12540137>. Accessed: May 20, 2011. doi: 10.1016/j.vetmic.2009.01.015.

BAUMS, C.G. et al. Diagnostic multiplex PCR for toxin genotype of Clostridium perfringens isolates. Veterinary Microbiology, v.100, p.11-16, 2004. Avaliable from: <http:/ /www.ncbi.nlm.nih.gov/pubmed/15135508>. Accessed: May 20, 2011. doi: 10.1016/S0378-1135(03)00126-3

DELMÉE, M. Laboratory diagnosis of Clostridium difficile disease. Clinical Microbiology and Infection, v.7, n.8, p.411416, 2001. Avaliable from: <http://www.ncbi.nlm.nih.gov/pubmed/ 11591203>. Accessed: May 20, 2011.

FEDORKO, D.P.; WILLIAMS, E.C. Use of cycloserinecefoxitin-fructose agar and L-proline-aminopeptidase (PRO Discs) in the rapid identification of Clostridium difficile. Jounal of Clinical Microbiology, v.35, n.5, p.1258-1259, 1997. Avaliable from: <http://www.ncbi.nlm.nih.gov/pubmed/ 9114419>. Accessed: May 20, 2011.
GONÇALVES, C. et al. Prevalence and characterization of a binary toxin (actin-specific ADP-ribosyltransferase) from Clostridium difficile. Jounal of Clinical Microbiology, v.42, n.5, p.1933-1939, 2004. Avaliable from: <http:// www.ncbi.nlm.nih.gov/pubmed/15131151>. Accessed: May 20, 2011 .

KEEL, M.K.; SONGER, J.G. The comparative pathology of Clostridium difficile-associated disease. Veterinary Pathology, v.43, n.3, p.225-240, 2006. Avaliable from: <http:// www.ncbi.nlm.nih.gov/pubmed/16672570>. Accessed: May 20, 2011. doi: 10.1354/vp.43-3-225.

KUIJPER, E.J. et al. Nosocomial outbreak of Clostridium difficile-associated diarrhea due to a clindamycin-resistant enterotoxin A-negative strain. European Journal of Clinical Microbiology \& Infectious Diseases, v.20, n.8, p.528-534, 2001. Avaliable from: <http://www.ncbi.nlm.nih.gov/pubmed/ 11681431>. Accessed: May 20, 2011.

KYNE, L. et al. Asymptomatic carriage of Clostridium difficile and serum levels of IgG antibody against toxin A. New England Journal of Medicine, v.342, n.6, p.390-397, 2000. Avaliable from: <http://www.ncbi.nlm.nih.gov/pubmed/10666429>. Accessed: May 20, 2011 . doi: 10.1056/ NEJM200002103420604.

LEMÉE, L. et al. Multiplex PCR targeting tpi (triose phosphate isomerase), $t c d A$ (Toxin A), and $t c d B$ (Toxin B) genes for toxigenic culture of Clostridium difficile. Jounal of Clinical Microbiology, v.42, n.12, p.5710-5714, 2004. Avaliable from: <http://www.ncbi.nlm.nih.gov/pubmed/15583303>. Accessed: May 20, 2011. doi: 10.1128/JCM.42.12.5710-5714.2004.

PERSSON, S. et al. New multiplex PCR method for the detection of Clostridium difficile toxin A $(t c d A)$ and toxin $\mathrm{B}(t c d B)$ and the binary toxin $(c d t A / c d t B)$ genes applied to a Danish strain collection. Clinical Microbiology and Infection, v.14, p.1057-1064, 2008. Avaliable from: < http:// www.ncbi.nlm.nih.gov/pubmed/19040478 >. Accessed: May 20, 2011. doi: 10.1111/j.1469-0691.2008.02092.x.

POST, K.W. et al. Evaluation of a test for Clostridium difficile toxins A and B for the diagnosis of neonatal swine enteritis. Journal of Veterinary Diagnostic Investigation, v.14, n.3, p.258-259, 2002. Avaliable from: <http://www.ncbi.nlm.nih.gov/ pubmed/12033686>. Accessed: May 20, 2011.

RODRIGUEZ-PALACIOS, A. et al. Clostridium difficile in retail ground meat, Canada. Emerging Infectious Diseases Journal, v.13, n.3, p.485-487, 2007. Avaliable from: <http:/ /www.ncbi.nlm.nih.gov/pubmed/17552108>. Accessed: May 20, 2011 .

RUPNIK, M. et al. Revised nomenclature of Clostridium difficile toxins and associated genes. Journal of Medical Microbiology, v.54, p.113-117, 2005. Avaliable from: <http:/ /www.ncbi.nlm.nih.gov/pubmed/15673503>. Accessed: May 20, 2011 .

SCHWAN, C. et al. Clostridium difficile toxin CDT induces formation of microtubule-based protrusions and increases adherence of bacteria. PLos Pathogens, v.5, n.10, e1000626, 2009. Avaliable from: <http://www.ncbi.nlm.nih.gov/pubmed/ 19834554>. Accessed: May 20, 2011. doi: 10.1371/ journal.ppat.1000626. 
SONGER, J.G.; UZAL, F.A. Clostridial enteric infections in pigs. Journal of Veterinary Diagnostic Investigation, v.17, n.6, p.528-536, 2005. Avaliable from: <http:// www.ncbi.nlm.nih.gov/pubmed/16475510>. Accessed: May 20, 2011 .

SONGER, J.G. et al. Prevention of porcine Clostridium difficile associated disease by competitive exclusion with nontoxigenic organisms. Veterinary Microbiology, v.124, n.4, p.358-361, 2007. Avaliable from: <http://www.ncbi.nlm.nih.gov/pubmed/ 17493774>. Accessed: May 20, 2011. doi: 10.1016/ j.vetmic.2007.04.019.

SONGER, J.G. et al. Clostridium difficile in retail meat products, USA, 2007. Emerging Infectious Diseases Journal, v.15, n.5, p.819-821, 2009. Avaliable from: <http:// www.ncbi.nlm.nih.gov/pubmed/19402980>. Accessed: May 20, 2011 .

SONGER, J.G. Clostridia as agents of zoonotic disease. Veterinary Microbiology, v.140, p.399-404, 2010. Avaliable from: <http://www.ncbi.nlm.nih.gov/pubmed/19682805>. Accessed: May 20, 2011. doi: 10.1016/j.vetmic.2009.07.003.

STUBBS, S. et al. Production of actin-specific ADPribosyltransferase (binary toxin) by strains of Clostridium difficile. FEMS Microbiology Letters, v.186, p.307-312, 2000. Avaliable from: <http://www.ncbi.nlm.nih.gov/pubmed/ 10802189>. Accessed: May 20, 2011.

VOTH D.E.; BALLARD J.D. Clostridium difficile toxins: mechanism of action and role in disease. Clinical Microbiology Reviews, v.18, n.2, p.247-263, 2005. Avaliable from: <http://www.ncbi.nlm.nih.gov/pubmed/15831824>. Accessed: May 20, 2011. doi: 10.1128/CMR.18.2.247263.2005

YAEGER, M. J. et al. A prospective, case control study evaluating the association between Clostridium difficile toxins in the colon of neonatal swine and gross and microscopic lesions. Journal of Veterinary Diagnostic Investigation, v.19, n.1, p.52-59, 2007. Avaliable from: <http://www.ncbi.nlm.nih.gov/ pubmed/17459832>. Accessed: May 20, 2011. 